\title{
Dvě další knihy o jazykovém kontaktu
}

Raymond Hickey, ed.:

\section{The Cambridge Handbook of Areal Linguistics.}

Cambridge: Cambridge University Press 2017. XVII + $1005 \mathrm{~s}$.

ISBN 978-0-107-05161-4.

Bridget Drinka:

\section{Language Contact in Europe: The Periphrastic Perfect through History.}

Cambridge: Cambridge University Press 2017. XVII + $487 \mathrm{~s}$.

ISBN 978-0-521-51493-4.

1. Jazyková kontaktologie a areálová lingvistika jsou dnes kvetoucí disciplíny a kvetoucí je dnes také žánr handbooku. Proto nepřekvapí, že také nakladatelství Cambridgeské univerzity vydalo svůj handbook k areálové lingvistice (HICKEy 2017). Knize je předeslán editorův úvod, vysvětlující, co je to jazykový areál, a resumující obsah svazku (HickEY 2017, 1-15). Pak se kniha rozpadá do dvou oddílů. V prvním, menším oddíle se pojednává o tématech areálové lingvistiky (Hickey 2017, 17-236): různí autoři v jednotlivých kapitolách píšou o tom, proč je obtížné definovat jazykový areál, jaký je vztah mezi jazykovým areálem a jazykovými univerzálii, jak pojmout pojem jazykového svazu, jak se areálové vztahy mohou projevovat ve fonologii a v lexikální sémantice. Druhý, větší oddíl pak tvoří případové studie, pojednávací o různých jazykových areálech světa (HICKEY 2017, 237-996); jsou zde germánské jazyky, britské ostrovy, variety angličtiny, slovanské jazyky, Kavkaz, Anatolie, Afrika, nilosaharská oblast, nigerkonžské jazyky, jižní Afrika, východní Indie a Nepál, Srí Lanka a jižní Indie, pády na severovýchodní Sibiři, Čína, Indočína, tóny v jihovýchodní Asii, Austrálie, Nová Guinea, východní Melanézie, západní Mikronézie, indiánské jazyky severní Ameriky, Amazonie a jižní Amerika.

Svazek má charakter obvyklý u jiných handbooků, o nichž jsme v poslední době referovali i v tomto časopise (málo jasný výběr dílčích témat, malá koherence jednotlivých kapitol, málo jasný adresát svazku). Obvyklé jako u jiných handbooků, o nichž jsme v poslední době referovali i v tomto časopise, je také hodnocení: v knize se najdou zajímavá konkrétní jazyková data nebo pěkné obecné postřehy (např. na s. 34 výzva soustředit se na zkoumání fungování jazykových areálů spíš než na jejich definici nebo na s. 74 úvaha o imperiálním pozadí jazykových svazů), ale kdyby svazek nevznikl, tak by se asi také nic nestalo.

2. Zajímavější nám přijde druhá kniha, o níž zde chceme stručně referovat (DRINKA 2017). Jejím tématem je historie perifrastického perfekta v jazycích Evropy. Po čtyřech úvodních obecných kapitolách, v nichž autorka představuje samo téma a bádání o něm, definuje Evropu jako jazykový areál, vymezuje kategorii perfekta a ukazuje diachronní zdroje této kategorie v indoevropských jazycích, přicházejí konkrétní kapitoly věnované perifrastickému perfektu v jednotlivých jazycích, resp. oblastech Evropy. Nejdříve se píše o perfektu v řečtině a latině, dvou evropských vůdčích jazycích, pak o perfektu v jazycích jazykového svazu Karla Velikého (s jeho německo-francouzským jádrem) a nato v románských jazycích a raných germánských jazycích, včetně pojednání o jejich vztazích ke karlovskému sprachbundu v tomto 
ohledu. Potom je zařazena kapitola $\mathrm{k}$ otázce sémantického posunu od perfekta $\mathrm{k}$ préteritu, kořenícího podle autorky rovněž ve zmíněném jazykovém svazu. Nato se pokračuje kapitolami o perfektu na Balkáně, o l-ovém perfektu v církevní slovanštině a v severoslovanských jazycích, o novém rezultativu v jazycích kolem Baltského moře a o posesivním rezultativu v severoslovanských a baltských jazycích. Knihu uzavírá koncízní shrnutí, vyzdvihující zejména, že existovala dvě evropská centra šíření perifrastického perfekta - řecké a latinské, že posesivní perfektum je západoevropské unikum, že kognitivní procesy předpokládají sociální kompetence $\mathrm{k}$ jejich uchopení a že jazykové areály je třeba pojímat stratifikovaně.

Atraktivita tématu evropského perifrastického perfekta spočívá v tom, že je to dobře viditelný a tak potenciálně emblematický jev, který se proto může propojit s mimojazykovými souvislostmi kulturními či sociopolitickými. Badatelé pak pomocí perfekta mohou např́klad „hierarchizovat Evropu“ (Standard Average European s „pravým“ perfektovým jádrem) nebo ji - jako autorka - podle parametrů konkrétních perfekt kulturně-areálově rozčlenit do „řecké“ a „latinské“ zóny, rozčlenitelných pak ještě dále, a to př́ípadně opět hierarchizovaně. Takové implikace jsou zábavné i explikativně plodné. Jen to vyžaduje také náležitou opatrnost, protože badatel přitom může snadno uklouznout. Je to vidět i na této knížce. Autorka načrtává velkolepou markroperspektivu - sugestivní jazykověkontaktové linie a sugestivní kongruence jazykových jevů s jevy mimojazykovými, ale trochu větší potíž je s mikroperspektivou - vylíčením konkrétních jazykových dat a konkrétních mechanismů předpokládaných kontaktů a kongruencí. Tak například bohemista najde neřídká klopýtnutí, která v něm pak vzbudí nedůvěru stran adekvátnosti prezentovaných dat z jiných konkrétních filologií (např. nekongruentní posesivní rezultativum v češtině na s. 378, pokud jde o data, a „extremely large German population“ na Hané na téže straně, pokud jde o mechanismy, anebo jedno - vlastně už docela veselé - klopýtnutí, spojující oba aspekty: na s. 338 autorka čte V.M. v českém dopise z roku 1556 jako Vuestra Merced a má to za ukázku toho, jak silný tehdy byl vliv Habsburků v českých zemích...). Přirozeně bychom mohli také doplňovat literaturu k dílčím tématům (slavista by doplnil např́lklad MCANALLEN 2011; BRANKAČKEC 2014; Sokolova 2017). Těší mě rovněž, že na s. 392 autorka sama a nezávisle vyložila litevskou konstrukci habere + part. pret. akt. stejně jako svého času recenzent (srov. VYKYPĚL 2006, 127). Konečně lze přivítat, že svým důrazem na neostrost a hierarchizovanost jazykových svazů (zejm. kap. 14) se autorka vrací k autentickému, pražskostrukturalistickému, pojetí tohoto pojmu, lingvistickým provozem zapomenutému (srov. k tomu VYKYPĚL 2016, 115-116).

Ale vcelku knihu pro podnětnost jejích témat i autorčiných nápadů čtenářům $\mathrm{k}$ opatrné pozornosti doporučujeme.

\section{LITERATURA}

BRANKaČKeC, Katja. 2014. Distribution und Funktionen von Vergangenheitsformen im älteren Obersorbischen. Eine empirische Untersuchung unter Berücksichtigung der Verhältnisse im Altpolnischen und Alttschechischen. Frankfurt am Main etc.: Peter Lang. 
Drinka, Bridget. 2017. Language Contact in Europe: The Periphrastic Perfect through History. Cambridge: Cambridge University Press.

Hickey, Raymond, ed. 2017. The Cambridge Handbook of Areal Linguistics. Cambridge: Cambridge University Press.

MCANALlen, Julia. 2011. The History of Predicative Possession in Slavic: Internal Development vs. Language Contact. Berkeley: University of California (disertace také dostupná z: https:// escholarship.org/uc/item/23r8p63b).

Sokolova, Anastasija. 2017. Slavjanskie preterity s istoričeskoj točki zrenija: $k$ istorii form perfekta $v$ russkom jazyke (na materiale služebnych minej na maj XI-XIII vv.). Brno: Masarykova univerzita.

VYкyрЕ̌L, Bohumil. 2006. Recenze: Björn Wiemer, Markus Giger: Resultativa in den nordslavischen und baltischen Sprachen (München: LINCOM Europa 2005). Acta linguistica Lithuanica 54, 123-129.

VYKYPĚL, Bohumil. 2016. Perspektiven auf die Geschichte des Tschechischen und die tschechische Geschichte. München: LINCOM Europa.

\section{Bohumil Vykypěl}

Czech Language Institute of the CAS, v. v. i.

Veveř́ 97,602 oo Brno

Czech Republic

vykypel@iach.cz 